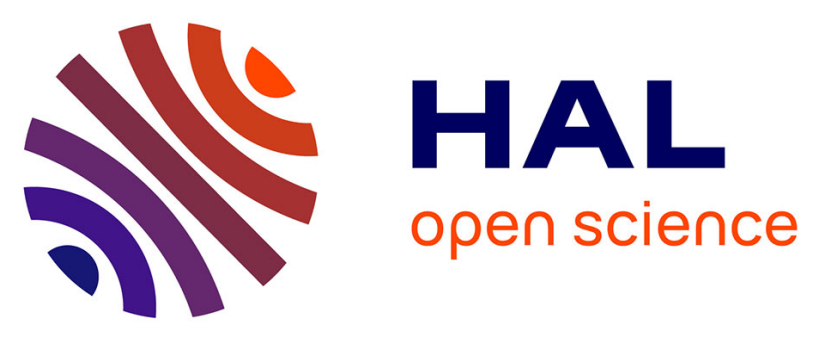

\title{
Monitoring of the mass and heat transfers through a heterogeneous karstic limestone vadose zone of an agricultural field (Beauce Aquifer, Orleans, France)
}

Bouamama Abbar, Clara Jodry, Arnaud Isch, Gautier Laurent, Mohamed Azaroual

\section{To cite this version:}

Bouamama Abbar, Clara Jodry, Arnaud Isch, Gautier Laurent, Mohamed Azaroual. Monitoring of the mass and heat transfers through a heterogeneous karstic limestone vadose zone of an agricultural field (Beauce Aquifer, Orleans, France). EGU General Assembly 2020, May 2020, Online, France. 10.5194/egusphere-egu2020-5294 . hal-03554441

\author{
HAL Id: hal-03554441 \\ https://hal.science/hal-03554441
}

Submitted on 3 Feb 2022

HAL is a multi-disciplinary open access archive for the deposit and dissemination of scientific research documents, whether they are published or not. The documents may come from teaching and research institutions in France or abroad, or from public or private research centers.
L'archive ouverte pluridisciplinaire HAL, est destinée au dépôt et à la diffusion de documents scientifiques de niveau recherche, publiés ou non, émanant des établissements d'enseignement et de recherche français ou étrangers, des laboratoires publics ou privés. 
EGU2020-5294

https://doi.org/10.5194/egusphere-egu2020-5294

EGU General Assembly 2020

(c) Author(s) 2022. This work is distributed under

the Creative Commons Attribution 4.0 License.

\title{
Monitoring of the mass and heat transfers through a heterogeneous karstic limestone vadose zone of an agricultural field (Beauce Aquifer, Orleans, France)
}

\author{
Bouamama Abbar ${ }^{1}$, Clara Jodry ${ }^{2}$, Arnaud Isch $^{3}$, Gautier Laurent ${ }^{4}$, and Mohamed Azaroual ${ }^{5}$ \\ ${ }^{1}$ Institut des Sciences de la Terre d'Orléans, France (bouamama.abbar@cnrs-orleans.fr) \\ ${ }^{2}$ Institut des Sciences de la Terre d'Orléans, France (clara.jodry@cnrs-orleans.fr) \\ ${ }^{3}$ Institut des Sciences de la Terre d'Orléans, France (arnaud.isch@cnrs-orleans.fr) \\ ${ }^{4}$ Institut des Sciences de la Terre d'Orléans, France (gautier.laurent@univ-orleans.fr) \\ ${ }^{5}$ Institut des Sciences de la Terre d'Orléans, France (m.azaroual@brgm.fr)
}

The extent and the fluid dynamics of the vadose zone (VZ) of an aquifer have a direct impact on the aquifer recharge, the water quality and the pollutants transfer from the soil to the groundwater. The water - rock interactions and mass and heat transfers under the impact of microbial processes and agricultural practices could undergoes significant changes in the chemical composition of the water flowing throughout the VZ, which may induce pollution of groundwater.

The growing dependence on groundwater for potable water supplies draws attention to protect the quality of groundwater resources at national and international levels to the need. It is important to detect the contamination risk of aquifers and develop an integrated water management methodology based on innovative environmental monitoring tools and sophisticated numerical models to protect groundwater resources and guarantee their good quality for domestic, agricultural and industrial needs. For this reason, the monitoring of VZ dynamics has become essential to study the transfer mechanisms of mass (water, gas and contaminants) and heat from the soil to the groundwater. This should allow rapid detection of the pollutants migration through an aquifer and take relevant measures to protect groundwater before the contaminants reach the water table.

In this context, an Observatory of transfers in the vadose zone (O-ZNS) is being developed at Villamblain (Orléans, France) in an agricultural field. The O-ZNS project consists of a well with a diameter of $4 \mathrm{~m}$ and a depth of $20 \mathrm{~m}$ which will allow access to the entire VZ of the Beauce aquifer. The main target of the O-ZNS platform is to acquire original and unique data on the reactive transfers of fluids and heat in the VZ, in order to follow in situ and in real time the highly coupled physical, chemical, and biological processes taking place over the long term. The O-ZNS project also aims to assess the performance of all types of instrumentation dedicated to non-destructive measurement or local sampling of fluids, rocks, and microbs in the VZ for long duration.

To meet these objectives, a myriad of innovative monitoring tools (e.g.,environmental sensors, 
fiber optic sensors, geophysical imaging, ....) will be deployed in the O-ZNS from the soil surface to the aquifer (from 0 to $20 \mathrm{~m}$ deep) using the well and the surrounding boreholes. Also, note that to date, there are still difficulties in the instrumentation of rock materials and relevant solutions must be developed. These environmental monitoring techniques will allow to generate a huge quantity of data on the physical, chemical, and microbiological coupled processes. 